\title{
KARAKTERISTIK DISTRIBUSI MINERAL UBAHAN: JEJAK EPISODE KEGIATAN HIDROTERMAL DI DAERAH CUPUNAGARA, SUBANG, JAWA BARAT
}

\author{
T.A.F.Sumantri* dan Sudarsono*
}

T.A.F.Sumantri dan Sudarsono, Karakteristik Distribusi Mineral Ubahan: Jejak Episode Kegiatan Hidrotermal di Daerah Cupunagara, Subang, Jawa Barat, RISET - Geologi dan Pertambangan Jilid 16 No.2 Tahun 2006, hal 61-71. 6 gambar

\begin{abstract}
Cupunagara Area, lies in the North-Northeastern of the Sunda Volcanic Complex, occupied by rough mountainous area consisting of two calderas and surrounded by several volcanic cones. The lithology of the studied area consists of intrusive rocks unit, andesitic - basaltic lava and pyroclastic, mostly had been altered into prophylitic and argillic zones. The prophylitic zone is distributed widely in the central part of the calderas, whilst the argillic zone is distributed confined to the NorthwestSoutheast trending fault zones overprints the prophylitic zone and contains the remnants of quartz veins.

Structural geology pattern of the studied area is affected by its position as the meeting area of the Cimandiri and the Baribis Fault Systems. Two main strike slip faults are recognized consist of the Northeast-Southwest trending sinistral fault and the NorthwestSoutheast trending dextral fault.

Two episodes of hydrothermal activities occurred in the studied area, in the first episode the hydrothermal fluid was relatively hot (temperature between $>100$ to $250^{\circ} \mathrm{C}$ ) and neutral (pH 5-6), whilst in the second its temperature was $<100^{\circ} \mathrm{C}$ and acid.

The first episode was triggered by the Oligo-Miocene tectonic activity (the formation of the Northeast-Southwest fault zone), the controlling factor of the hydrothermal alteration distribution were the permeability of the host rocks and fault zones, altered the mineralogy of the host rocks into the prophylitic alteration assemblage and formed quartz veins. The second episode was triggered by the Plio-Pleistocene tectonic activity (the formation of the Northwest-Southeast fault zone), altered (overprinted) the wall rocks into the argillic alteration assemblage, the controlling factor was the fault zones.
\end{abstract}

Sari : Daerah Cupanagara terletak di sebelah Utara-Timurlaut Kompleks Gunungapi Sunda, dengan morfologi berupa pegunungan kasar dibentuk oleh dua kaldera dan dikelilingi oleh beberapa kerucut volkanik. Litologi terdiri atas satuan batuan intrusi, lava dan piroklastik berkomposisi andesitis - basaltis, sebagian besar terubah menjadi zona ubahan propilitik dan argilik. Zona propilitik tersebar luas pada bagian tengah kaldera, sedangkan zona argilik penyebarannya terbatas pada zona sesar Baratlaut-Tenggara, menggantikan (overprint) zona propilitik, mengandung sisa-sisa urat kuarsa.

Pola struktur dipengaruhi posisinya pada pertemuan Sistem Sesar Cimandiri dan Baribis, dua sesar geser utama dikenali yaitu sesar geser kiri berarah TimurlautBaratdaya dan sesar geser kanan berarah Baratlaut-Tenggara.

Dua episode kegiatan hidrotermal berkembang di daerah penelitian; Pada episode pertama, fluida hidrotermal berkarakter netral $(\mathrm{pH}$ 5-6) dengan temperatur berkisar dari $>100$ sampai $250^{\circ} \mathrm{C}$, sedangkan pada episode kedua fluida hidrotermal berkarakter asam (pH 4) dengan temperatur $<100^{\circ} \mathrm{C}$.

Episode pertama dipicu kegiatan tektonik Masa Oligo-Miosen (pembentukkan zona sesar Timurlaut-Baratdaya) faktor pengontrol penyebaran berupa permeabilitas batuan dan zona sesar/lemah, merubah mineralogi batuan samping menjadi zona propilitik dan pembentukkan urat kuarsa. Episode kedua dipicu kegiatan tektonik Masa Plio-Pleistosen (pembentukkan zona sesar Baratlaut-Tenggara), merubah mineralogi batuan samping menjadi zona argilik, yang penyebarannya dikontrol oleh zona sesar/lemah.

*Pusat Penelitian Geoteknologi - LIPI

Kata kunci : Daerah Cupunagara, propilitik, argilik, "overprint", episode kegiatan hidrotermal. 


\section{PENDAHULUAN}

Daerah Cupunagara, secara administratif berada di bawah pemerintahan daerah Kecamatan Cisalak, Kabupaten Subang, Propinsi Jawa Barat, dan secara geografis terletak diantara $107^{\circ} 50^{\prime}-108^{\circ} 00^{\prime}$ BT dan $06^{\circ} 42^{\prime}-06^{\circ} 46^{\prime}$ LS. Bentang alamnya disusun oleh pegunungan berelief kasar dengan ketinggian berkisar dari 500 sampai $1500 \mathrm{~m}$ dpl., terdiri atas Kaldera Cibitung di bagian barat yang dipotong oleh Kaldera Cupunagara di bagian timur yang berumur Paleogen, tubuh intrusi, dan beberapa kerucut gunungapi yang merupakan bagian Gunung Sunda berumur Kuarter (Gunung Canggak, Pasir Bedil, Pasir Batulawang, Kandaka, dan Bukit Tunggul) yang mengelilingi daerah penelitian. Kedua kaldera, membuka ke arah utara dengan sisi selatan yang sangat curam, terisi oleh endapan kolovium di bagian dasarnya. Penentuan umur berdasarkan K-Ar memberikan $59 \mathrm{Ma}$ (Paleosen Akhir) untuk batuan andesitis Kaldera Cibitung dan 36,9 Ma (Oligosen Awal) untuk Kaldera Cupunagara (Utoyo, H. dkk., 2004). Sungai Cupunagara merupakan sungai utama tempat bermuaranya sungai-sungai lain membentuk pola aliran konsentris. Beberapa air terjun yang terbentuk oleh sesar normal berarah Timur - Barat dijumpai memotong aliran Sungai Cibitung, Cikendung, Cibadak, Ciwangun dan Cikaruncang, membentuk pola tangga dengan jarak antara 20 sampai $25 \mathrm{~m}$ sepanjang aliran sungai.

Indikasi mineralisasi hidrotermal seperti batuan ubahan, urat kuarsa, breksi hidrotermal, dan mineralisasi sulfida dilaporkan beberapa peneliti terdahulu seperti Sudarsono dkk. (2004, 2005), Bronto dkk. (2004), Utoyo dkk. (2004) dan PT Aneka Tambang Tbk (komunikasi pribadi). Tulisan ini bermaksud untuk mengungkap sejarah kegiatan hidrotermal di daerah penelitian melalui karakteristik distribusi asosiasi mineral ubahan, sehingga dapat dijadikan acuan dalam menentukan arah kegiatan eksplorasi mineral logam selanjutnya.

\section{GEOLOGI DAERAH PENELITIAN}

Daerah penelitian menempati bagian Timurlaut Kompleks Gunungapi Sunda, pada sisi utara Blok Pegunungan Selatan Jawa Barat yang berbatasan dengan Cekungan Bogor (Martodjojo, 1984; Pulunggono dkk., 1994), dan dianggap sebagai daerah pertemuan penerusan Sistem Sesar Cimandiri yang berarah TimurlautBaratdaya dari Zaman Kenozoik (OligoMiosen?) (Anugrahadi, 1993; Noeradi, 1994; Haryanto, 2004), dan Sistem Sesar Baribis yang berarah Baratlaut-Tenggara berumur PlioPleistosen (Bemmelen, 1949) (Gambar 1.)

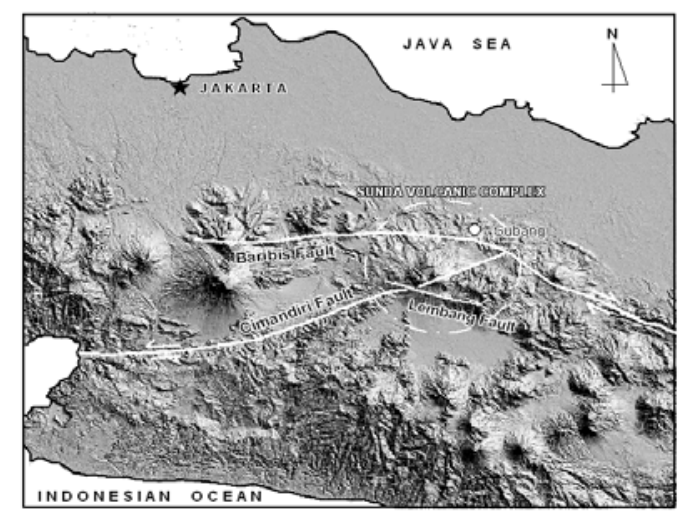

Gambar 1. Posisi regional geologi daerah penelitian di bagian Timurlaut Kompleks Gunungapi Sunda, dan sebagai daerah pertemuan penerusan Sistem Sesar Cimandiri yang berarah TimurlautBaratdaya dari Zaman Kenozoik (Oligo-Miosen?), dan Sistem Sesar Baribis yang berarah BaratlautTenggara berumur Plio-Pleistosen (Bemmelen, 1949; Anugrahadi, 1993; Noeradi, 1994; Haryanto, 2004).

Sejarah tektonik diawali pada Zaman OligoMiosen dengan pembentukan cekungan pengedapan yang diikuti proses pengendapan sedimen laut, batugamping (Bemmelen, 1949) dan aktifitas volkanisme (Utoyo, 2004), yang terus berlanjut sampai Zaman Neogen (Miosen Pliosen). Kegiatan tektonik tersebut mendeformasi dan memicu terjadinya kegiatan hidrotermal di daerah ini. Kegiatan gunungapi selanjutnya pada zaman Kuarter menghasilkan 
kerucut-kerucut gunung api di dalam Kompleks Gunungapi Sunda.

Di lapangan hal tersebut diperlihatkan oleh batuan hasil kegiatan gunungapi Kuarter, yang membentuk Kompleks Gunungapi Sunda (Bemmelen, 1949), yang menutupi batuan gunungapi yang berumur Paleogen yang masingmasing membentuk Kaldera Cibitung (59 Ma Paleosen Akhir) dan Kaldera Cupunagara (36,9 Ma - Oligosen Awal).

\section{Stratigrafi}

Menurut Van Bemmelen (1949) dan Silitonga (1973), batuan volkanik di daerah Cupunagara berumur Kuarter menumpang pada Tambakan Beds (Formasi Subang) yang berumur Pleistosen Awal. Batuan volkanik berkomposisi andesit piroksen membentuk Gunung Lingkung, Batulawang, dan Canggak yang mengelilingi daerah penelitian berumur Kuarter Tua. Sementara batuan volkanik tak teruraikan yang berkomposisi andesit piroksen sampai andesit basaltis yang membentuk Gunung Bukittunggul berumur Kuarter Muda. Soetoyo dan Hadisantono R.D, (1992) membagi hasil gunung api Tangkuban Perahu yang berumur Kuarter Muda menjadi empat satuan stratigrafi gunung api sebagai berikut : Satuan Lava Pra Sunda, Satuan Aliran Piroklastik Sunda, Satuan Kerucut Gunungapi Pangparang, dan Satuan Endapan Piroklastik Tangkuban Perahu.

Sudarsono dkk. (2005) membagi litologi penyusun daerah penelitian menjadi : Satuan olivin basal sampai andesit basaltis yang menempati bagian selatan, satuan intrusi yang membentuk Gunung Orem dan Geulis di dalam kaldera, Satuan batuan ubahan propilitik, satuan batuan ubahan argilik, satuan lava dan piroklastik andesit Gunung Batulawang yang menempati bagian baratlaut, satuan lava dan piroklastik andesit Gunung Pasir Bedil yang menempati bagian timurlaut, satuan lava dan piroklastik andesit Gunung Canggak yang menempati bagian timur, dan satuan endapan kolovium yang menempati dasar bagian utara gawir kaldera (Gambar 2).

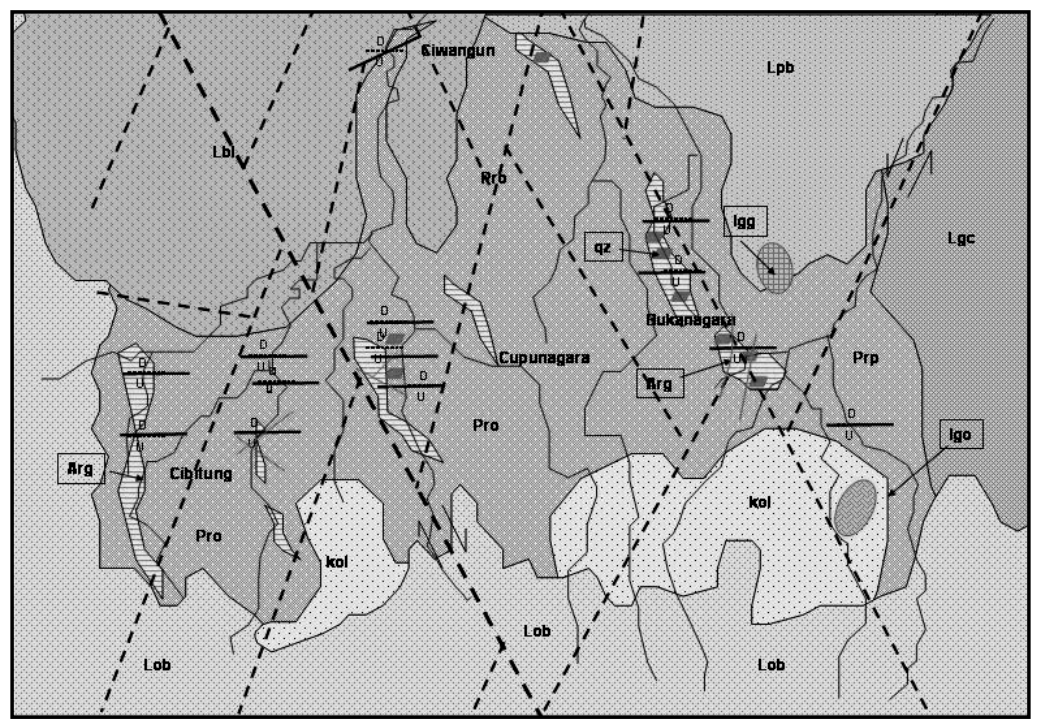

Gambar 2. Peta Geologi daerah penelitian (Sudarsono, dkk, 2005). Perhatikan karakter distribusi zona mineral ubahan argilik yang relatif searah dengan sesar geser menganan (BaratlautTenggara). Lob : volkanik basalt olivin, Kol : kolovium, Igo : intrusi Gn Orem, Lgc : volkanik Gn. Canggak, Lpb : volkanik Gn Pasirbedil, Lbl : volkanik Gn.Batulawang, Pro : Zona ubahan propilit, Arg : zona ubahan argilit. 


\section{Geologi struktur}

Pola geologi struktur yang berkembang di daerah penelitian sangat dipengaruhi posisi tektonik regionalnya diantara dua sistem sesar. Hal ini tercermin pada fitur kelurusan pada Citra Landsat yang diperlihatkan oleh punggungan bukit, lembah dan sungai didominasi oleh araharah Timurlaut-Baratdaya dan BaratlautTenggara, disamping beberapa kelurusan BaratTimur.

Pada kenampakan lapangan, fitur kelurusan diwakili oleh kekar, zona milonitisasi, bidangbidang sesar geser berarah Baratlaut-Tenggara dan Timurlaut-Baratdaya, dan bidang sesar normal berarah Barat-Timur.

Pada citra landsat sesar geser berarah BaratlautTenggara merupakan sesar geser kanan sedangkan sesar geser Timurlaut-Baratdaya merupakan sesar geser kiri. Sesar geser kanan memotong sesar geser kiri dan Kaldera Cibitung. Sesar-sesar normal berarah Barat-Timur membentuk tangga air terjun kecil dengan jarak antara 25 - 30 meter pada sepanjang aliran Sungai Cikendung, Cibitung, Cibadak, dan Cikaruncang, dibatasi di bagian barat oleh sesar geser kanan dan di bagian timur oleh sesar geser kiri.

\section{PETROGRAFI}

\section{Petrografi batuan}

Batuan daerah penelitian tersusun oleh batuan gunungapi berkomposisi intermedier sampai basa yang terdiri atas lava berkomposisi andesitis sampai basaltis, batuan piroklastik, dan batuan intrusi. Sebagian besar batuan telah mengalami ubahan dengan intensitas yang bervariasi, yang secara umum memperlihatkan asosiasi mineral ubahan klorit + karbonat + epidot + serisit + silika + K-felspar + mineral lempung, tersebar luas di daerah penelitian terutama di Kaldera Cibitung dan Cupunagara.

Batuan intrusi terdiri atas andesit basaltis dan diorit hornblen. Komposisi mineralogi andesit basaltis dicirikan oleh hadirnya klorit + karbonat menggantikan sebagian hornblen, dan mineral lempung yang menggantikan K-felspar. Batuan diorit hornblen dijumpai sebagai bongkah di aliran Sungai Cikendung tersusun oleh plagioklas dan hornblen dengan ukuran kristal mencapai $4 \mathrm{~mm}$ serta menyusun kira-kira 35\% mineralogi batuan (Gambar 3). Asiosiasi ubahan pada batuan ini terdiri atas klorit + karbonat + epidot + K-felspar + serisit + silika + gelas .
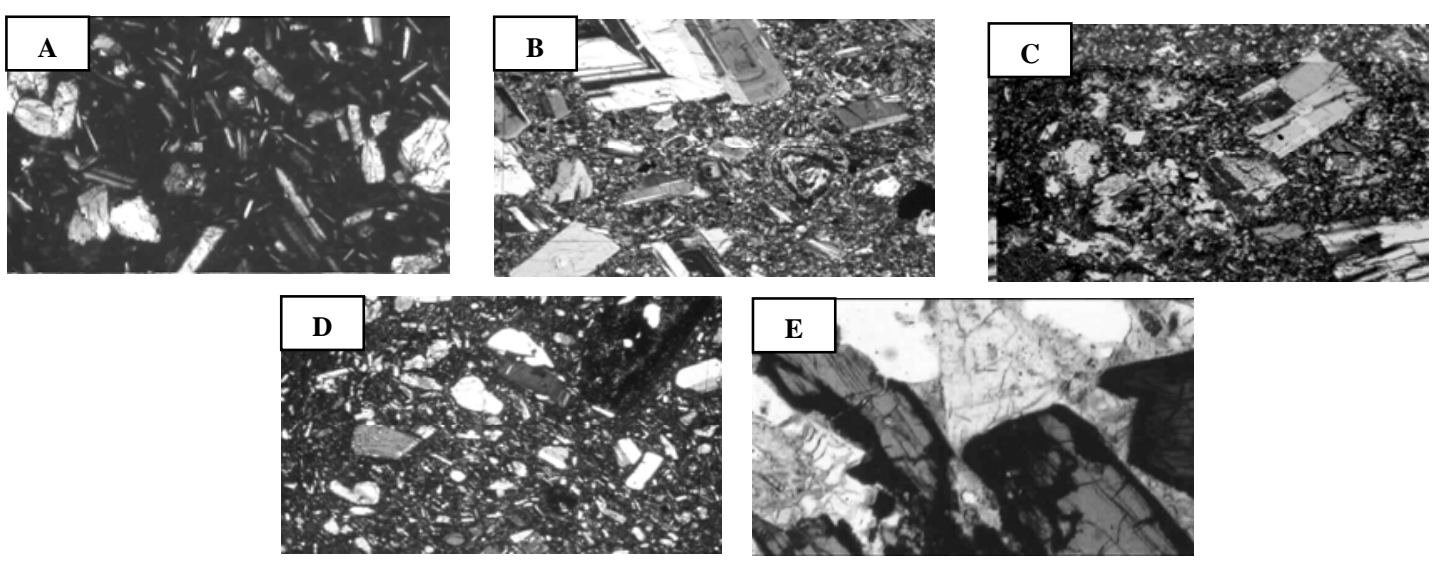

$\mathbf{0}$ $2 \mathrm{~mm}$

Gambar 3. Kenampakan mikroskopis sayatan tipis batuan A. Andesit piroksen (CGR-3B). B. Andesit basaltis dari Gunung Orem (ORE-01A) C. Basal porfir (CBT-02). D. Olivin basal (CPN01B). dan E. Diorit hornblen dari Sungai Cikendung (CKD-3C) (Indarto, 2006). 
Batuan ini oleh Bronto dkk. (2004) diperkirakan berasal dari ruang magma yang berperan sebagai sumber panas sistem hidrotermal daerah penelitian. Proses fraksinasi magma diorit menghasilkan batuan gunungapi daerah penelitian (Indarto, 2006).

\section{Mineragrafi dan XRD (Difraksi Sinar X)}

Analisis mineragrafi tujuh conto batuan memperlihatkan mineral bijih yang terbentuk terdiri atas pirit, sfalerit, kalkopirit, dan gutit. Secara umum, pirit selalu hadir berasosiasi denga sfalerit sering memperlihatkan tekstur eksolusi dimana sfalerit hadir sebagai inklusi dalam pirit. Pirit juga hadir sebagai material pengisi rongga. Pada conto lainnya, asosiasi pirit dan sfalerit hadir berasosiasi dengan kalkopirit dan gutit. Kalkopirit dan pirit memperlihatkan teksture simple-locking, sementara gutit hadir sebagai mineral sekunder hasil ubahan pirit.

Data Difraksi Sinar X menunjukkan kandungan mineral lempung conto dari zona mineral ubahan argilik tersusun oleh interlayer ilit-smektit, ilitklorit, smektit-klorit, kaolinit, smektit, dan haloysit.

\section{Inklusi Fluida}

Data inklusi fluida yang diperoleh dari conto sisa urat kuarsa pada zona mineral ubahan argilik, memberikan kisaran temperatur homogenesasi (pembentukan) dari 162 sampai $340^{\circ} \mathrm{C}$ walaupun demikian, semua conto mengindikasikan bahwa fluida hidrotermal mempunyai salinitas rendah, yaitu kurang dari 3 \%-berat ekifalen $\mathrm{NaCl}$ (Sumantri \& Setiawan, 2006). Hasil penentuan kedalaman pembentukkan conto urat kuarsa menunjukkan bahwa conto terbentuk pada kisaran kedalaman antara 65 sampai 215 m di bawah permukaan purba (paleosurface) dengan kedalaman rata-rata mencapai $100 \mathrm{~m}$.

\section{ZONA MINERAL UBAHAN}

Bagian tulisan ini merupakan simplifikasi studi detil oleh Setiawan (2006), sebagian besar batuan daerah penelitian telah mengalami ubahan yang dicirikan oleh asosiasi mineral ubahan yang tersusun oleh klorit, karbonat, epidot, serisit, silika, mineral lempung, K-felspar, pirit, kalcopirit, sfalerit, gutit, dan hematit. Berdasarkan asosiasi ini, daerah penelitian tersusun oleh dua zona mineral ubahan, yaitu : Zona Ubahan Propilitik dan Argilik (lihat Gambar 2).

\section{Zona mineral ubahan propilitik}

Zona ubahan ini dicirikan oleh asosiasi mineral ubahan K-felspar + serisit + klorit + pirit + karbonat + epidot + silika dan interlayer kloritilit + ilit-smektit + klorit-smektit yang berasosiasi dengan pirit + sfalerit + kalkopirit (Gambar 4).

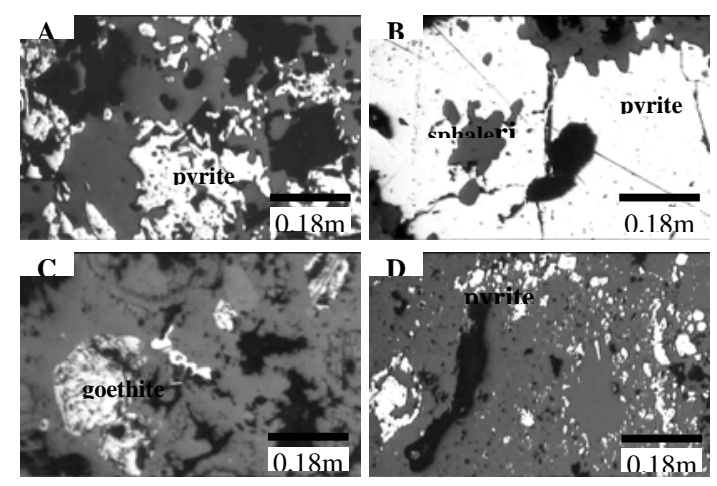

Gambar 4. Kenampakan mikroskopis mineralogi bijih conto batuan CKD 6 memperlihatkan pirit (foto A) dan tekstur exsolution (foto B) yang diperlihatkan oleh pirit dan sfalerit, pirit digantikan oleh gutit pada conto CPN 3 (foto $C$ ); dan granular pirit pada conto CPN 9B (foto $D$ ) (Setiawan. 2006).

Conto batuan yang mengandung K-felspar dan sericit dalam asosiasi mineral ubahan berasal dari dan berdekatan dengan zona sesar. Kehadiran K-felspar dan serisit pada zona ini mengindikasikan kisaran temperatur pembentukan antara $>200$ sampai $250^{\circ} \mathrm{C}$, sedangkan kehadiran interlayer ilit-smektit, klorit-ilit, dan klorit-smektit mengindikasikan kisaran temperatur pembentukan dari 100 sampai $200^{\circ} \mathrm{C}$ (Corbett dan Leach, 1996). Asosiasi mineral ubahan zona propilitik terbentuk dalam 
kondisi $\mathrm{pH}$ sedikit asam sampai netral ( $\mathrm{pH}$ 5-6; Leach dan Muchemi, 1987).

Penyebaran zona ubahan sangat luas menempati bagian tengah daerah penelitian, di bagian utara ditutupi oleh satuan batuan hasil gunungapi Gunung Batu Lawang dan Pasir Bedil, di bagian barat dan selatan ditutupi oleh Satuan Lava Basal Olivin dan endapan kolovium, sedangkan di bagian timur ditutupi oleh hasil gunungapi Gunung Canggak (lihat Gambar 2).

\section{Zona mineral ubahan argilik}

Zona mineral ubahan ini dicirikan oleh asosiasi silika + kaolin + smektit + hematit + haloysit yang berasosiasi dengan pirit + sfalerit + kalkopirit + gutit, penyebaran zona terbatas pada fitur geologi struktur yang berarah BaratlautTenggara di dalam zona ubahan propilitik (lihat Gambar 2).
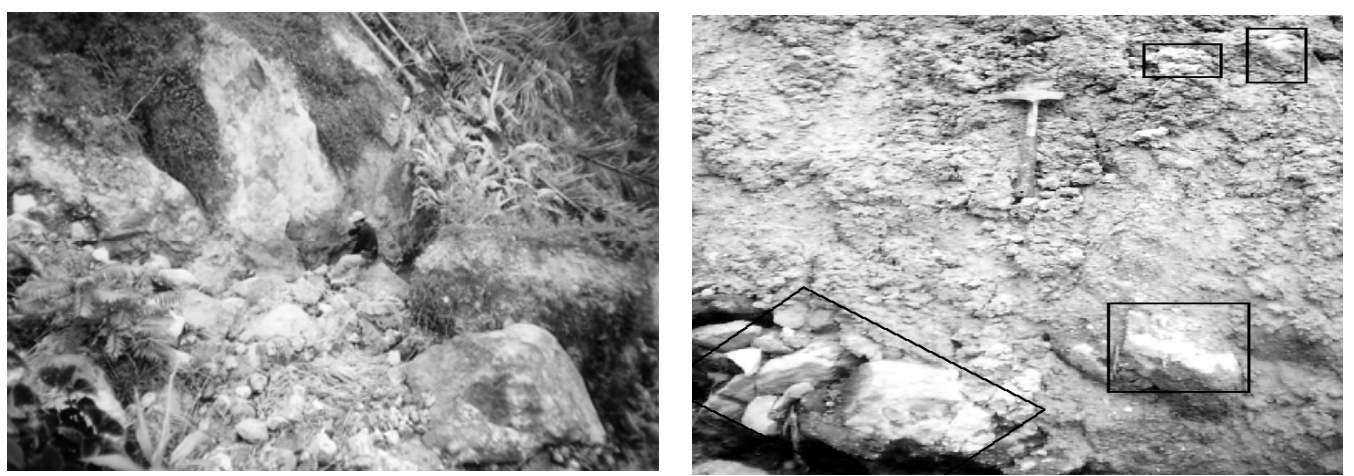

Gambar 5. Singkapan zona mineral ubahan argilik di Sungai Cikendung (foto kiri), dan nampak dekat bagian dari singkapan memperlihatkan sisa-sisa urat kuarsa berukuran kerikil sampai berangkal yang tersebar di bawah palu (dalam kotak, foto kanan) (Sumantri dan Setiawan, 2006). 


\section{PEMBAHASAN}

\section{Perkembangan pola geologi struktur}

Pola geologi struktur yang berkembang di daerah penelitian sangat dipengaruhi oleh posisi tektonik regionalnya sebagai daerah pertemuan antara dua sistem sesar besar. Hal ini dicerminkan oleh pola unsur geologi struktur dan kelurusan pada citra Landsat yang didominasi oleh arah-arah Baratlaut-Tenggara dan Timurlaut-Baratdaya sebagaimana diperlihatkan oleh Diagram Rosette dalam insert pada Gambar 6. Berdasarkan kesamaan arah dan pergerakan relatif, dan hubungan potong memotong yang terlihat pada citra dan data lapangan; Dapat diasumsikan bahwa arah kelurusan TimurlautBaratdaya dipengaruhi oleh (merupakan bagian dari) sistem sesar Cimandiri sedangkan arah Baratlaut-Tenggara dipengaruhi oleh (merupakan bagian dari) sistem sesar Baribis.
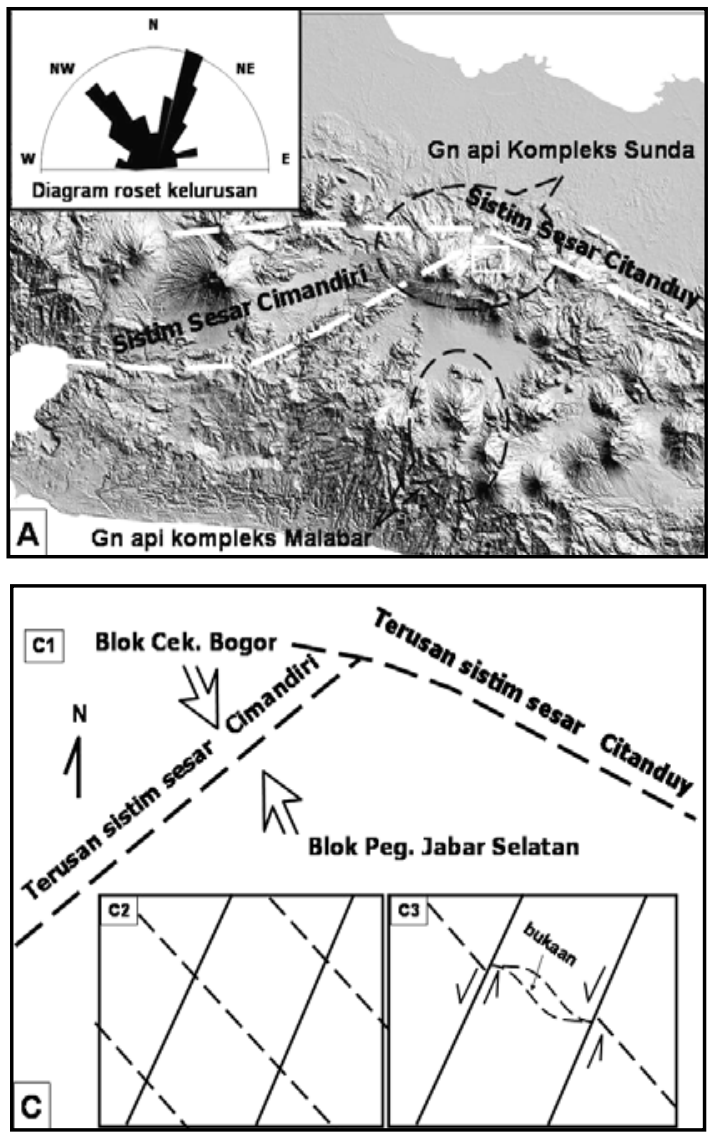

Asumsi lainnya, pola kelurusan daerah penelitian dapat merupakan suatu conjugate shear yang dihasilkan oleh sistem sesar Baribis yang berarah relatif Timur-Barat, walaupun demikian dalam tulisan ini asumsi ini dikesampingkan mengingat hal ini harus didasarkan pada ataupun ditunjang data pengukuran lapangan yang lengkap.

Dalam perkembangan geologi struktur daerah penelitian, berdasarkan model yang dipergunakan oleh Riedel (hal. 145, Price dan Cosgrove, 1990) diperkirakan pada saat aktifnya sistem sesar Cimandiri (Oligo-Miosen?) terbentuk unsur-unsur geologi struktur pada batuan penutup berupa sesar geser kiri yang berarah Timurlaut-Baratdaya, dan kekar-kekar terbuka (gash fractures) yang berarah BaratlautTenggara (Gambar 6).
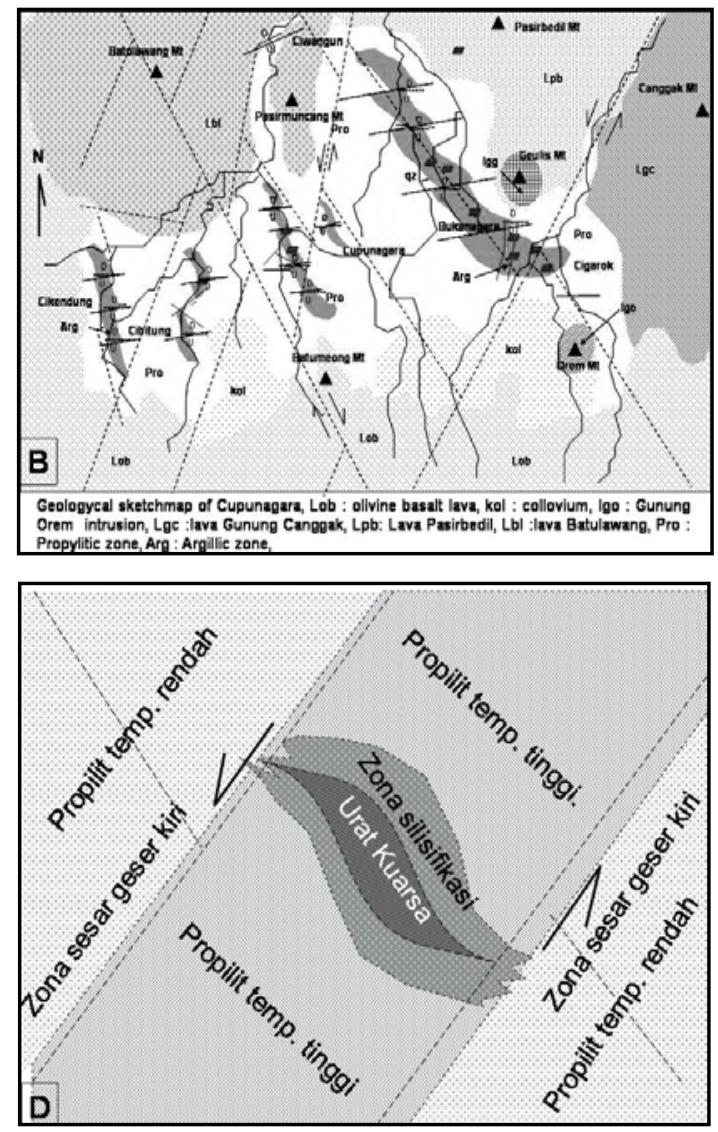

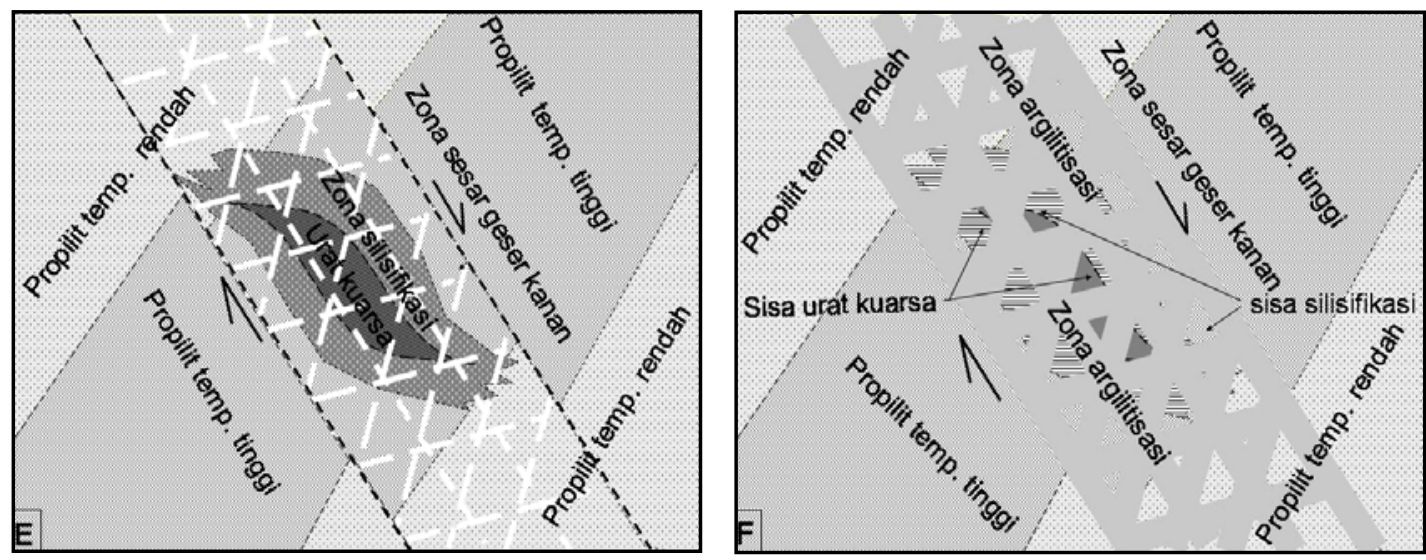

Gambar 6. Rekonstruksi sejarah kegiatan hidrotermal di daerah penelitian (dimodifikasi dari Sudarsono, 2006). A dan $B$. Memperlihatkan posisi tektonik regional dan peta geologi daerah penelitian yang menunjukkan karakteristik distribusi zona ubahan argilik. C. Interaksi antara unsurunsur struktur geologi menghasilkan pasangan arah unsur geologi struktur berarah Timurlaut-Baratdaya dan Baratlaut-Tenggara.. Saat unsur Timurlaut-Baratdaya berkembang menjadi sesar geser kiri, unsur struktur Baratlaut-Tenggara menjadi kekar terbuka (tension/gash fracture). D. Pembentukkan zona mineral ubahan propilitik temperatur tinggi pada zona sesar dan temperatur rendah pada batuan samping, serta pengisian kekar terbuka oleh kuarsa (pembentukkan urat kuarsa) dalam envelope batuan tersilisifikasi. E. Kekar gerus (sekarang menjadi urat kuarsa) berkembang menjadi sesar geser kanan, memotong sesar geser kiri. F. Pembentukkan zona ubahan argilik pada zona sesar geser kanan arah Baratlaut -Tenggara dengan sisa-sisa batuan silisifikasi dan urat kuarsa.

Pada kegiatan tektonik selanjutnya, diperkirakan berkaitan dengan aktifnya sistem sesar Baribis (Plio-Pleistosen), terbentuk unsur-unsur geologi struktur berupa sesar geser kanan yang berarah Baratlaut-Tenggara memotong batuan dan semua fitur geologi struktur yang sebelumnya terbentuk.

\section{Karakteristik penyebaran zona mineral ubahan}

Kegiatan tektonik yang berlangsung merupakan pemicu kegiatan hidrotermal di daerah penelitian, dalam hal unsur-unsur geologi struktur yang terbentuk merupakan zona lemah batuan dan berfungsi sebagai saluran naiknya fluida hidrotermal kepermukaan. Kecepatan fluida hidrotermal yang naik ke permukaan melalui zona lemah/sesar relatif lebih cepat apabila dibandingkan dengan fluida yang naik melalui (permeabilitas) batuan, sehingga interaksi fluida dengan batuan samping ataupun dengan air meteorik terjadi relatif singkat, akibatnya temperatur fluida hidrotermal relatif tidak mengalami penurunan yang signifikan. Hal ini akan tercermin dengan hadirnya mineralmineral ubahan propilitik temperatur tinggi seperti K-felspar dan serisit pada batuan samping di sekitar zona lemah/sesar. Zona kekar terbuka yang berarah Baratlaut-Tenggara terisi oleh kuarsa membentuk urat-urat kuarsa dalam envelope batuan tersilisifikasi. Hal sebaliknya, kecepatan naiknya fluida hidrotermal pada batuan diluar zona-zona lemah relatif lambat karena sangat dipengaruhi oleh permeabilitas batuan. Hal ini mengakibatkan fluida hidrotermal mengalami interaksi dengan batuan samping yang lebih dingin dan mengalami penurunan temperatur sehingga assosiasi mineral ubahan yang terbentuk berupa ubahan propilitik temperatur rendah. Di daerah penelitian, proses tersebut terjadi karena dipicu oleh pembentukkan ataupun aktifnya Sesar Cimandiri. Pada kegiatan tektonik selanjutnya, diperkirakan 
berkaitan dengan aktifnya sistem sesar Baribis, terbentuk sesar geser kanan berarah relatif Baratlaut-Tenggara memotong batuan dan semua fitur geologi struktur yang sebelumnya terbentuk, termasuk deformasi urat-urat kuarsa yang terbentuk pada zona kekar terbuka. Zona sesar yang terbentuk menjadi saluran baik bagi naiknya fluida hidrotermal kepermukaan, maupun infiltrasi air meteorik ke dalam. Karakteristik air meteorik yang dingin dan kaya kandungan oksigen, merubah karakter fluida hidrotermal menjadi bersifat asam, sangat korosif, dan mengakibatkan penggantian mineralogi batuan propilitik dan "memakan"urat kuarsa yang telah mengalami deformasi, menghasilkan batuan ubahan argilik yang mengandung sisa-sisa urat kuarsa. Pada episode ini, penyebaran zona ubahan lebih banyak dikontrol oleh zona lemah, sementara permeabilitas batuan (dapat dikatakan) tidak berperan mengingat proses ubahan propilitik telah mengubah batuan samping menjadi bersifat impermeable.

\section{Sejarah kegiatan hidrotermal}

Beberapa data yang diperoleh seperti : penggantian zona ubahan propilitik oleh zona ubahan argilik, karakter penyebaran ubahan, kandungan sisa-sisa urat kuarsa pada zona ubahan argilik, didukung oleh data inklusi fluida dan hubungan potong memotong antara zona sesar yang berhubungan dengan mineralisasi, menyarankan paling tidak telah terjadi dua episode kegiatan hidrotermal yang dipicu oleh kegiatan tektonik di daerah penelitian.

Episode kegiatan yang pertama terjadi saat kegiatan magmatis dipicu oleh kegiatan tektonik selama Zaman Kenozoikum (Oligo-Miosen?) pada saat aktifitas Sistem Sesar Cimandiri, yang membentuk zona sesar yang berarah TimurlautBaratdaya dan berfungsi sebagai saluran bagi fluida hidrotermal naik ke permukaan. Pada awal proses kegiatan, fluida hidrotermal berkarakter sedikit asam sampai netral ( $\mathrm{pH} \mathrm{5-6)} \mathrm{dan} \mathrm{panas}$ (temperatur berkisar dari $>200^{\circ} \mathrm{C}$ sampai $250^{\circ} \mathrm{C}$ ), sebagaimana tercermin dari asosiasi mineral ubahan berupa K-feldpar + serisit + klorit + pirit (Leach dan Muchemi, 1987; Corbett dan Leach, 1996). Dalam perjalanan ke permukaan melalui batuan samping, temperatur fluida hidrotermal mengalami pendinginan hingga antara $>100^{\circ} \mathrm{C}$ sampai $150^{\circ} \mathrm{C}$, mengubah mineralogi batuan samping ke dalam asosiasi mineral ubahan propilitik yang terdiri atas klorit + karbonat + epidot + silika dan interlayer mineral lempung, seperti klorit-ilit + ilit-smektit + klorit-smektit dengan asosiasi mineral bijih pirit + sfalerit + kalkopirit.

Pada proses penurunan temperatur selanjutnya tercapai kondisi fisika dan kimia yang kondusif untuk pengendapan urat kuarsa dalam envelope zona ubahan silisifikasi yang terjadi pada zonazona lemah/sesar.

Kegiatan tektonik selama Masa Plio-Pleitosen pada saat aktifitas Sistem Sesar Baribis membentuk zona sesar berarah BaratlautTenggara sekaligus memicu terjadinya episode kedua kegiatan hidrotermal. Dalam perjalanan menuju permukaan melalui zona-zona lemah/sesar yang terbentuk, fluida hidrotermal yang semula berkarakter relatif netral dan panas mengalami perubahan karakter menjadi asam dan mengalami penurunan temperatur karena bercampur dengan air meteorik yang dingin dan kaya akan oksigen. Melihat penyebaran zona ini secara vertikal ditunjang data inklusi fluida, diperkirakan air meteorik yang kaya oksigen dan dingin masuk sampai kedalaman $\pm 100 \mathrm{~m}$ melalui zona sesar/lemah, sebelum bercampur dengan fluida hidrotermal., yang disebabkan oleh pressure drawn-down karena mendinginnya magma. Karakter asam fluida hidrotermal sangat korosif dan merusak mineralogi asosiasi ubahan propilitik yang terbentuk sebelumnya, hal ini dapat menjelaskan penyebaran zona ubahan argilik yang terbatas pada zona-zona sesar/lemah yang berarah relatif Baratlaut-Tenggara dan pergantian mineralogi asosiasi ubahan propilitik serta kandungan sisa-sisa urat kuarsa pada zona argilik (Gambar 2 dan 6).

Zona mineral ubahan ini dicirikan oleh asosiasi silika + kaolin + smektit + hematit + haloysit yang berasosiasi dengan pirit + sfalerit + kalkopirit + gutit. Asosiasi ini mencerminkan fluida hidrotermal yang berkarakter asam ( $\mathrm{pH} 4)$ dan mempunyai temperatur $<100^{\circ} \mathrm{C}$ (Leach dan Muchemi, 1987, dan Corbett dan Leach, 1996). 


\section{KESIMPULAN}

Pola geologi struktur yang terbentuk di daerah penelitian sangat dipengaruhi oleh posisi tektonik regionalnya, yaitu sebagai pertemuan dua sistem sesar utama (Sesar Cimandiri dan Baribis). Aktifitas kedua sistem sesar tesebut menghasilkan pola kelurusan unsur struktur yang didominasi arah Timurlaut-Baratdaya dan Baratlaut-Tenggara.

Dua episode kegiatan hidrotermal di daerah penelitian dipicu oleh kegiatan tektonik, yang masing-masing terjadi pada Zaman Kenozoikum (Oligo-Miosen?) dan Plio-Pleistosen. Pada awal episode kegiatan hidrotermal yang pertama (diperkirakan berhubungan dengan aktifnya Sesar Cimandiri) fluida hidrotermal berkarakter sedikit asam sampai netral (pH 5-6) dan panas $\left(>200^{\circ} \mathrm{C}-250^{\circ} \mathrm{C}\right)$ mengubah mineralogi batuan samping menjadi asosiasi mineral ubahan propilitik temperatur tinggi yang terdiri atas $\mathrm{K}$ felspar + serisit + klorit + pirit.

Penurunan temperatur fluida hidrotermal terutama karena berinteraksi dengan batuan samping menjadi $>100^{\circ} \mathrm{C}-200^{\circ} \mathrm{C}$, menghasilkan asosiasi mineral ubahan propilitik temperatur rendah, yang terdiri dari klorite + karbonat + epidot + silika dan interlayer klorite-ilit + ilitsmektit + klorit-smektit dan asosiasi mineral bijih pirit + sfalerit + kalkopirit, mengendapkan urat kuarsa dalam envelope batuan silisifikasi pada zona-zona sesar/lemah. Faktor pengontrol utama pada kegiatan ini adalah permeabilitas batuan dan zona sesar/lemah.

Fluida hidrotermal pada episode kedua (Zaman Plio-Pleistosen, diperkirakan berhubungan dengan aktifnya Sesar Baribis) berkarakter asam (pH 4) dengan temperatur rendah $\left(<100^{\circ} \mathrm{C}\right)$, sebagai hasil bercampur dengan air meteorik yang dingin dan kaya oksigen pada kedalaman \pm 100 m. Karakter fluida hidrotermal "memakan" semua fitur yang dihasilkan pada kegiatan hidrotermal episode pertama, menggantikannya menjadi asosiasi mineral ubahan silika + kaolin + smektit + hematit + haloysit yang berasosiasi dengan pirit + sfalerit + kalkopirit + gutit. Faktor pengontrol utama pada kegiatan ini adalah zona sesar/lemah, sebagaimana ditunjukkan oleh pola penyebaran zona yang terbatas pada zona sesar/lemah yang berarah Baratlaut-Tenggara.

\section{UCAPAN TERIMA KASIH}

Pekerjaan lapangan dilakukan sebagai bagian dari Proyek Penelitian Puslit Geoteknologi-LIPI, untuk ini ucapan terimakasih ditujukan kepada Bapak Kapuslit, Dr. H. Herry Harjono. Juga ucapan terimakasih untuk para anggota Kelompok Penelitian Mineralisasi Hidrotermal lainnya, Ir. Indarto dan Ir. Setiawan, untuk seluruh diskusi yang telah dilakukan hingga tersusunnya tulisan ini. Tidak lupa kepada Ir. Tito Soempono dan seluruh krew yang telah memberikan bantuan berupa penggunaan fasilitas Laboratorium GIS. Akhirnya tetapi bukan yang paling akhir, ucapan terimakasih ditujukan kepada Sdr. Kuswandi yang telah banyak membantu dalam mempersiapkan preparasi batuan.

\section{DAFTAR PUSTAKA}

Anugrahadi, A., 1993. Tegasan terbesar Sesar Cimandiri Timur Kabupaten Bandung Jawa Barat. Proc. PIT IAGI. Bandung. 6-9 Des. : 226-240.

Bronto, S., Achnan K., and Utoyo, H., 2004. Penemuan sumber baru mineralisasi di Daerah Cupunagara, Kecamatan Cisalak Kabupaten Subang Jawa Barat, Electronic Proceeding of the 33rd PIT IAGI, Bandung

Corbett, G.J., and Leach, T.M., 1996. Southwest Pacific Rim Gold-Cooper Systems: Structure, Alteration and Mineralization. Workshop Manual: 186pp.

Haryanto, I., 2004. Tektonik Sesar BaribisCimandiri. Electronic Proceeding of the 33rd PIT IAGI , Bandung.

Indarto, I., 2006. Petrography and geochemistry of volcanic rocks at Cupunagara Area, Subang Regency, West Java. Proceedings of the $9^{\text {th }}$ International Symposium on Mineral Exploration (ISME IX). 19-21 September 2006. ITB. Bandung. 
Leach, T.M., and Muchemi, G.G., 1987. Geology and hydrothermal alteration of the north and west exploration wells in the Olkaria geothermal field, Kenya. Proc. The 9th geothermal workshop : 187-192.

Martodjojo, S., 1994. Evolusi Cekungan Bogor Jawa Barat. Doctorat Thesis ITB : 396 pp.

Noeradi, D., Villemin, T., Rampnoux, J.P., 1994. Paleostresses and strike slip movement : the Cimandiri Fault Zone, West Java, Indonesia. Journal of Southeast Asian Earth Science 9. No. 1 / 2 : 3-11.

Price, N.J., and Cosgrove, J.W., 1990. Analysis of Geological Structures. Cambridge University Press, pp. 502.

Pulunggono, A., Martodjojo, S., 1994. Perubahan tektonik Paleogen dan Neogen merupakan peristiwa tektonik terpenting di Jawa. Proc. Geologi dan geoteknik P. Jawa sejak akhir Mesozoik hingga Kuarter : 3750.

Setiawan, I., 2006. Mineralization and mineral assemblages in hydrothermally altered rocks at Cupunagara Area, Subang, West Java. Proceedings of the $9^{\text {th }}$ International Symposium on Mineral Exploration (ISME IX). 19-21 September 2006. ITB. Bandung.

Silitonga, P.H., 1973, Peta Geologi Lembar Bandung, Jawa, skala 1 : 100.000, Direkt. Geologi, Bandung.

Soetoyo \& R.D. Hadisantono, 1992, Peta Geologi GunungapiTangkubanparahu, Komplek Gunungapi Sunda, Jawa Barat, skala 1 : 50.000, Direkt. Vulkanologi, Bandung.
Sudarsono, 2006, Structural controls on hydrothermal mineralization at Cupunagara, Subang, West Java. Proceedings of the $9^{\text {th }}$ International Symposium on Mineral Exploration (ISME IX). 19-21 September 2006. ITB. Bandung.

Sudarsono, Sri Indarto, Toto A.F. Sumantri, Iwan Setiawan, Kuswandi dan Zaenal, 2005, Model Mineralisasi hidrotermal di Daerah Cupunagara, Kabupaten Subang, Jawa Barat (Sub GT07), Laporan Penelitian Proyek Penelitian Sumberdaya Mineral dan Mitigasi Bencana Kebumian, Pusat Penelitian Geoteknologi -LIPI, Bandung.

Sumantri, T.A.F., Setiawan, I., 2006. Fluid inclusion study of quartz vein in hydrothermal mineralization, Cupunagara, Subang Regency, West Java. Proceeding of the 3rd International Symposium on Earth Resources and Geological Engineering Education. Yogyakarta, 3-4 August 2006.

Utoyo, H., Mesker H.J.D., Bronto, S., and Kaspar L.B, 2004. K-Ar age of volcanic rocks in Cipunegara, Subang, West Java. Electronic Proceeding of the 33rd PIT IAGI, Bandung.

Utoyo, H., S. Bronto \& Achnan, K., 2004, Alterasi dan Mineralisasi Kaldera Purba di daerah Cupunagara, Subang - Jawa Barat, Prosid. Forum Litbang SDM, BESDM, Jakarta, 7-8 Sept., 2004.

Van Bemmelen, R.W., 1949. The Geology of Indonesian. Vol. 1A. Government Printing Office. The Hague : 732 pp. 